Informasi - ISSN (p) 0126-0650; ISSN (e) 2502-3837

Vol. 50, No. 1 (2020), pp. 46-57, doi: http://doi.org/10.21831/informasi.v50i1. 27861

\title{
Blaming the victim: Representation the victim of rape in M.F.A film
}

\author{
Titik Indriyana \\ Master of Communication Studies, Diponegoro University \\ titikindriyana@gmail.com \\ Choirul Ulil Albab \\ Department of Communication Studies, Dian Nuswantoro University \\ ulil.dinus@gmail.com
}

Article History: Received 2019-10-29, Revised 2020-07-20, Published 2020-07-30

\begin{abstract}
The media in representing rape victims is still gender biased, such as blaming the victim. This study aims to find out how female victims of rape are shown in the M.F.A film by using semiotics to analyze the structure and ideology contained in the text. The theory used by researchers to analyze texts (M.F.A.) is the concept of radical feminism. Radical feminism argue, women must have control over their bodiesThe results of the research show in the M.F.A. film, women are shown as sexual objects of men. Women are represented as having to accept anything, including their fate when raped by men. They are not given the strength to resist and only accept it. Even in the eyes of the public and the law, women who are rape victims are still weak and are actually cornered (blaming the victim). Reports of rape are considered fabricated and have no strong evidence. In the film M.F.A. women who demanded their rights were silenced, by patriarchal ideologies. What's worse is the silence of a woman, because they have been hegemony in patriarchal ideology.
\end{abstract}

Media dalam merepresentasikan korban perkosaan masih bias gender. Bahkan menyalahkan korban (blaming the victim). Penelitian ini bertujuan untuk mengetahui bagaimana perempuan korban perkosaan ditampilkan dalam film M.F.A dengan menggunakan semiotika untuk menganalisis struktur dan ideologi yang terdapat di dalam teks. Konsep yang digunakan peneliti untuk menganalisis teks (Film M.F.A.) adalah feminisme radikal. Feminis radikal berpendapat, perempuan harus memiliki kendali atas tubuh mereka.Hasil penelitian menunjukkan dalam Film M.F.A., perempuan diperlihatkan sebagai objek seksual dari laki-laki. Perempuan direpresentasikan harus menerima apapun, termasuk nasibnya ketika diperkosa oleh laki-laki. Mereka tidak diberikan kekuatan untuk melawan dan hanya menerimanya. Di mata masyarakat dan hukum pun, perempuan korban perkosaan masih lemah dan justru disudutkan (Blaming the Victim). Laporan mengenai perkosaan dianggap mengada-ada dan tidak memiliki 
bukti yang kuat. Dalam Film M.F.A. perempuan yang menuntut hak-haknya dibungkam, oleh ideologi-ideologi patriarki. Yang lebih parah lagi adalah yang membungkam juga seorang perempuan, karena mereka telah terhegemoni ideologi patriarki.

Keywords: Blaming the Victim, Representation, Woman, Radical Feminism

\section{INTRODUCTION}

Annual records of the National Women's Commission (Komisi Nasional Perempuan, 2019) compiled from various service institutions in Indonesia from 2007 to 2017 recorded a total of 25,522 to 348,446 cases of violence against women each year, with a tendency to increase in number from year to year (Susanty \& Julqurniati, 2019).

Among these are cases of sexual harassment. Annual Notes in 2019 The National Commission on Violence Against Women shows in the public and community domain, violenceagainstwomen was recorded in 3,915 cases. $64 \%$ of violence against women in the public sphere or community is sexual violence, such as molestation $(1,136)$, rape (762) and sexuall harassment (394). This figure is still considered high (Komisi Nasional Perempuan, 2019). Ironically the media in representing rape is also gender bias. Even worse, by blaming the victims.

One of the media which is closely related to the issue of female sexual violence is film. Film is a cultural art work which is a social institution and mass communication media made based on cinematographic rules with or without sound and can be performed. Basically, films always influence and shape society from the messages contained therein (Tanjung \& Ramanda, 2019). Film cannot be denied until now it is still one of the media idolized by the public in meeting entertainment needs. The film still has appeal through a variety of themes that are presented, so as to absorb the audience. This can be seen from the many film genres, from fantasy, action and violence.

One of them is the phenomenon of exploitation of a woman's body, where the woman's body and the nature of womanhood are used as a tool to attract public interest (Jaya, 2014). In the film, women are still portrayed as weak figures. Violence and rape are still attached to women. Women are helpless figures and are still the sex objects of men (Adipoetra, 2016). Women become objects, objects or commodities. Men always have full autonomy over their own bodies while women do not (Laoera, 2016).

In presenting reality, the media often has their own problems. The media sometimes places and even reinforces the stereotypes of some groups such as women. No exception in the film. As a media, the representation of reality cannot be separated from bias, in this context it is women. The media is an agent with a strong potential to carry out socialization and social change, give status, encourage stereotypes (Byerly, 2006).

It's as McLuhan said that the media is a message. Through this expression, McLuhan wants to state that the media has power and gives influence to society (Morissan, 2013).

In line with McLuhan, Stuart Hall also said that the media is an instrument of power of the elite, and the media serves to convey the thoughts of groups that dominate society (Morissan, 2013). That the function of the media is to represent the interests of the capital owner, or the party who finances the media. There is no media that is free of value/importance. Whether it's economic, political, social or cultural interests.

The film in showing women, their filmmakers can not be avoided from certain values/ideologies, such as patriarchy and capitalism. The patriarchal ideology subtly entered into the film, both visual, oral, gestures, and narrative, which then oppressed women. As the director M.F.A described the figure of Noelle. Rape victims in this film are described as weak, powerless women. Even positioned in the position of being blamed. Once there is construction.

Patriarchal culture still dominates all lines of people's lives. Society in a patriarchal system defines women based on standards set by men. This construction causes an 
imbalance of power between men and women. Men create rules and women follow the norms made by men. Unfortunately this construction was also agreed by the mass media. One of them is a film.

Many films have not provided a positive picture of women. Especially women victims of sexual violence. The way the media presents women victims of sexual violence is still very patriarchal and gender biased. The media tends to perpetuate the status quo of the dominant gender ideology by continuing to display men in superior positions. As seen in the film M.F.A.

M.F.A. is a 2017 American thriller film directed by Natalia Leite and written by Leah McKendrick. The film stars Francesca Eastwood, Clifton Collins Jr., Leah McKendrick, Peter Vack, David Huynh, Marlon Young, David Sullivan, Michael Welch and Mike Manning. The film was released on October 13, 2017, by Dark Sky Films.

M.F.A. tells the story of Noelle. Noelle, an introvert California fine arts graduate student, accepts an invitation to a party by a handsome classmate she has a crush on, only to be lured into his room where he rapes her. The following night Noelle confronts her rapist and in a moment of rage, accidentally kills him.

Because they feel they don't get justice from law enforcement, Noelle becomes a pitiless vigilante who uses her newly-found sex-appeal to serve her cause. When she attacks the man who many years before assaulted her friend Skye, she is found out by Skye and later the police. At the end, after the ceremony in which she receives her Master of Fine Arts degree and speaks as valedictorian, she is arrested.M.F.A. was chosen because this film tells the struggle of women victims of sexual violence in depthand was nominated for a Grand Jury Award in 2017.

M.F.A directed by Natalia Leite reveals the sad side of a rape victim girl named Noelle. When Noelle reported the case to the school. She was treated unfairly as if he wanted him to be raped. Likewise, when other rape victims, Lindsey was called by the police, instead she was bombarded with cornering questions, such as how many times she had sex with other men.

This injustice of women's representation contradicts to Article $28 \mathrm{D}$ paragraph 1 of the 1945 Constitution, namely that everyone has the right to the recognition, guarantee, protection, and fair legal certainty and equal treatment before the law.

The school and the police should not position the victim as the perpetrator. Of the several questions raised by the school to Noelle and Lindsey, the diction used to direct the allegations to the victims, that the victims also enjoyed the rape. Schools that should provide assistance to victims actually blame the victims. The authorities who should be able to give a sense of justice and comfort also blame the victim.

Blaming the victim cannot be separated from the role of mass media. Today's mass media, there is little information, shows that represent gender-sensitive rape victims. The media have not given a positive picture to women victims of rape. The way the media presents women victims of rape is still very patriarchal and gender-biased.

Themediaisstillconsideredanapparatus. The media becomes a tool to transfer dominant ideologies to society. And films are still one form of shows that are often used by the mass media in influencing audiences. In the film tucked into the interests of those in power. Ironically, under the pretext of winning the market, film producers often use issues that are considered to be able to attract consumers (viewers), such as sexuality, where women are presented as an object that is exploited for profit.

In the midst of a strong patriarchal culture and swift information and shows such as films, M.F.A comes with the issue of rape, where men have power over women, while women have no power over themselves. Based on the description above, the formulation of the problem in this study is how women rape victims are shown in the film M.F.A.

This study aims to find out how female 
victims of rape are shown in the M.F.A film by using semiotics to analyze the structure and ideology contained in the text. The theory used by researchers to analyze texts (M.F.A.) is the concept of radical feminism.

Theresearch related to therepresentation of rape victims was presented by Dani Marsa Aria Putri entitled Blaming The Victim: Representation of Women Rape Victims in Mass Media (Semiotic Analysis in News in Suara Merdeka Newspaper December 2011 February 2012) (Putri, 2012). Data retrieval is done by syntagmatic and paradigmatic analysis in semiotics. The result is known that the Suara Merdeka daily newspaper presents rape victims as passive, weak and helpless when dealing with rape perpetrators. Women are considered guilty of almost every news. Many of the stigma and labels pinned on victims of rape have a negative impact on the psychological victim.

In addition, the media packs cases of harassment and violence to women with a male perspective so that the victims experience pressure. Yulianto Budi Setiawan in his research entitled Analysis of Critical Discourse on Gender-Based Violence Reporting in the Suara Merdeka Daily Newspaper, said that media workers still had not received workshops on gender. Instead of giving empathy to victims, newspapers tend to misrepresent violence so they tend to put women in disgrace. The media portrays women as objects of sexual fantasy, harassment, and violence. The problem is how the media presents violence in their news. There seems to be no empathy for victims of violence against women (Setiawan, 2011).

The study used a qualitative descriptive technique with a critical perspective, this study analyzed qualitative data according to Norman Fairclough's Critical Discourse Analysis. After exploring the texts presented at Suara Merdeka daily news, the study found gender bias. This study shows that most journalists at Suara Merdeka found almost no opportunity to attend gender-related workshops, so the news output they produced did not cover both sides of the story.
Another study was Anna Puji Lestari's research entitled Blaming The Victim: Symbolic Violence in the Form of Gender Alienation in the Rape Victim in Asusila News in Suara Merdeka.Com. This study uses the theory of gender structuration with the support of the concept of gender alienation as a theoretical guide toa qualitative approach in the critical paradigm through the framework of critical and feminist discourse analysis. This research is also supported by qualitative content analysis methods in the form of framing Entmant and reception analysis to see the consumption of blaming the victim text by the public (Lestari, 2018).

The results of the study stated that at the micro level, the occurrence of blaming the victim was due to the inclusion of rape victims as news sources (gender alliance). During this time, the speakers involved are those who are considered to have authority (police, Mayor, Deputy Mayor) but do not have gender awareness. The resource persons who were present tended to state that immoral events that occurred were based on sexual consent. That is, the resource persons considered that the victim enjoyed having sex with the perpetrator. In addition, at the micro level analysis, it was found the use of biased diction which assumed women as sex objects. Biased diction which is often used to describe the rape incident committed by a group of young hoodlums, which is "rotated". The use of the diction means equating the victim as an object that deserves to be hurt and "enjoyed" by the body.

The results of the research at the meso level include two things, namely the production practices and the consumption practices of blaming the victim text at Suaramerdeka.com. In the practice of text production, it is known that the practice of blaming the victim occurs due to several things, namely the first step in the process of executing a news search by journalists is not preferred to seek the opinion of other sources as a balance. The two SOPs on the treatment of sexual violence were limited to disguising the victim's name and not clearly revealing his identity. Thirdly in 
the monitoring process, often the news of sexual violence is not followed up (to achieve equilibrium) further and there is no evaluation from the Editor, Chief Editor, and Redpel. Fourth, there is no Redpel that deals with crime. Fifth, there is no gender training for Suaramerdeka.com personnel. While the findings related to the practice of text consumption states that generation $\mathrm{Z}$ as a potential reader of Suaramerdeka.com has dominantly interpreted the meaning offered by the media. Generation $\mathrm{Z}$ readers are one hundred percent sure that rape victims also enjoy sex with rapists.

This study uses a critical paradigm with a qualitative approach. The analysis process carried out is by Roland Barthes's semiotics model which describes the sign through three stages of meaning namely denotation, connotation, and myth. Through the elaboration of the three stages of meaning, the purpose of research into how rape victims are displayed will be known.

\section{LITERATURE REVIEW}

In conducting studies on the representation of women victims of rape in the M.F.A film, use the point of view of understanding representation as a view to see the phenomena in the film. This view describes the reality of someone's life, group, or other things in the media. There is something wrong with the representation carried out by the media, because the media only focuses on the upper class (men), and marginalizes the lower class (women). This representation study is very interesting to see there is an ideology hidden behind a questionable text.

Women have strategic positions in critical studies. Regarded as the second gender, the female figure is often the object of oppression, both directly and indirectly. Unconsciously, women are positioned to follow the flow of male thinking. So at that point, women are trapped in a patriarchal perspective. This representation study can see the point of view of the film in positioning a woman who is a rape victim who is fighting for a seemingly lame justice.
Frank Ankersmit explains the reason why we need representation is that it allows us to obtain and express insight into the nature of a phenomenon. That is why humans have artistic representations, historical representations, and political representations. But representation in other places is just as important. Representation defines reality, this shows reality as it is. But more than that; It also makes and shapes the human understanding of reality. We can know and access the world only through language, or representation (Webb, 2009).

In addition to representation, researchers also use feminism theory. The feminism movement was born in 196o. Its appearance in America is as part of the civil rights and sexual freedom movement. Feminist groups in America fight for the fate of women to fulfill practical rights such as childcare, health, education, and abortion. The movement then spread to Europe, Canada and Australia. (Fakih, 2008).

The results of these various movements can be seen with the issuance of a resolution to stop all forms of discrimination against women by the United Nations in 1979. And almost every country, now has antidiscrimination laws that pay attention to and favor women. However, it turns out that this major change in the field of law does not necessarily change the position of women in society.

Opening opportunities for women to take part in various aspects of life, apparently does not necessarily change the position of women. changes in the law, economic rights, politics, education, health, have not been able to fundamentally change the position of women in society. This change turned out to be just one drop in a sea of systems and structures of greater dominance. The views of society, curriculum, and religion, still perpetuate discrimination against women, and even resistance arises, one of which comes from the woman herself (Fakih, 2008).

Some sources of resistance that emerged in the community according to Mansour Fakih were: 
Backflow resistance by the women themselves. Allegations that feminism is actually seen as afflicting women rather than giving a sense of happiness. Changing the role of women from housewives to career women is considered to be a disaster for themselves. They suffer both physically and mentally because of too much equality. They think that the way women really want is to become a housewife or wife who is always at home and a mother who is proud of her motherhood.

The second resistance is called developmentalism. The word development is only a new package of the old contents of capitalism. Capitalism has always benefited from the oppression of women. therefore the issue of gender and women's liberation has never existed in the dictionary of developmentalism, it tends to perpetuate it (Fakih, 2008). The third challenge comes from patriarchal religious understanding. So far, religious teachings are accepted a priori as a single truth (Fakih, 2008).

\section{METHODS}

The study entitled Blaming The Victim in M.F.A Films is qualitative research with a critical paradigm. The perspective of this paradigm is to criticizeall forms of oppression (Lestari, 2017). This includes the oppression of the media industry against women in film.

The researcher wanted to find out how rape victims were shown in the M.F.A film by using semiotics to analyze the dominant structure and ideology contained in the text. Semiotics is the study of signs (Chandler, 2007). Semiotics is often used to analyzefilms. Film researchers will observe more signs in each scene than the storyline. Filmand semiotics are related to each other (Tanjung \& Ramanda, 2019). This study uses Roland Barthes's semiotics.

According to Barthes, the sign in a media actually represents an ideology or connotation that represents the dominant ideology of society (Barthes, 1974). Barthes tries to uncover the meanings contained in the text, by grouping meaning into two parts, namely the meaning of denotation and the meaning of connotation. Denotation means literal meaning, while connotation meaning is the second meaning or cultural meaning or meaning determined by the community. In denotation meaning, language presents conventions or social codes explicitly, where the meaning of the sign appears based on the relation of markers and markers. While the connotation meanings present codes whose meanings are implicit. The implicit meaning is a code system whose sign has a charge of hidden meanings. This hidden area according to Barthes is an area of ideology or mythology.

In his analysis, Barthes decapitated the text into lexis units. Lexia is reading units. This beheading cannot be denied to be arbitrary in extreme differences. Lexia includes a few words or sometimes a few sentences. Lexia is just a wrapper of semantic content, the outline of a plural text, arranged like a possible (but controlled, proven truth by a systematic reading) under the flow of continuous discourse. This means that the analysis with Roland Barthes's semiotics in the first stage is to cut off arbitrary text (at will). The decapitation of the text is to determine Lexia, both in the form of a word to a paragraph (Barthes, 1974).

In this analysis the data is in the form of text, the researcher will select the text, read the media text of the film entitled M.F.A., by retyping, copying the text to be studied. The next step is to find and analyze the meaning of denotations, connotations, and myths. Then interpret the idea or idea and dominance of power (ideology) behind the oppressive phenomenon experienced by the main character.

\section{RESULT AND DISCUSSION}

In this patriarchal Indonesian culture, rape tends to be seen from the point of view of men. Rape cases are always seen from the eyes of men. As a result, women are often victims. To explain how rape victims are displayed, 4 scenes are taken, which have blaming messages from victims of rape victims who have been analyzed using Roland Barthes's Semiotic theory. The results 
show that scenes in the M.F.A film represent women as objects.

The four scenes has been chosen by the researchers showed that female rape victims were displayed as if they were enjoying the sexual relationship. Because the victim is considered to be enjoying it, the victim must be responsible for the sexual violence that befell him. This is where blaming the victim happens. Almost all the women who were raped in the film could not provide significant resistance. They were beaten, even given drinks so they could not do anything. This is then mistaken for sexual pleasure by the victim. The resistance that Noelle tried to do did not work because the environment was not supportive.

\section{Representation of Women as a Rape Victims}

Women look like in a media which in this case is the film M.F.A. There are two interesting points of view about representation. First, whether a person or group is shown the media properly. This word as it should be 'refers to whether a person or group is displayed for what it is or is actually defaced. Second, how the representation is displayed. How an idea related to a person or group is conveyed through the media, whether with photos, pictures, writings, accents, or in the form of videos. How media represent someone or group is important in this study of representation (Webb, 2009).

The first point of view on the concept above answers that female victims of rape are usually introverted types. They are the types of people who are covered in their personal lives. After being raped the woman is shown with a face that is severely depressed. But they become strong and strong after they don't get the rights they should get. But there are a number of choices faced by these women, namely they still try to fight for their rights and take revenge (Noelle), choose to forget the past and open a new life (Skye), and decide to hide their past in order to stay strong against the world (Lindsey).

Extras in this film are shown to be very passive. They formed a discussion group based on the women's freedom movement and fighting for women's rights. But what happened was that this group was trapped in patriarchal thinking. They try to attract the attention of men with a variety of displays that actually trap them from the perspective of men.

The second representation perspective in the M.F.A. film, women are shown as sexual objects of men. Women are represented as having to accept anything, including their fate when they are raped by men. They are not given the strength to resist and only accept it. Even in the eyes of the law, women who are rape victims are still weak and are actually cornered. It is as if the reporter is a sensitive person and enjoys sexual relations. Reports of rape are considered fabricated and have no strong evidence. Women are depicted as helpless when they have to fight for their rights, to give appropriate punishment to men who rape.

Noelle as a woman was shown to have 'power' when she was a victim of rape. He struggled hard to demand justice for himself. In an environment that is not supportive, he does not give up to fight for his rights. Initially, he was a closed person, then his personality changed after he experienced this bitter thing.

Often women are trapped in the world of men and don't realize it. There are many aspects in this world that force women into this patriarchal circle. Language has an important role in leading women to enter into a patriarchal perspective. Language is usually a vehicle of representation, even though the language is not always representational. There are three language approaches in representation (Webb, 2009). (1) The first approach is related to reflectivity. Language only reflects or resembles the meaning that exists in the world. Not all words reflect something that already exists in reality. Some of them create reality. Language cannot only reflect or resemble a situation in the real world. Language can only be used to frame and interpret objects. (2) The second approach to language is a deliberateapproach. This is based on the assumption that each 
communication action conveys exactly what is intended by the communicator. As written by Stuart Hall (Webb, 2009), it is the speaker and author who imposes its uniqueness in the world through language. But there is a problem with this approach. In a condition, speakers and writers can only communicate in language codes and are limited in what they can say and how they can say it. (3) The third approach is the constructor approach to language. This includes the notion that meaning is not reflected or forced, but is actually built, in the process of making representations.

Language seems to be a spear ready to unleash rape victims. The stairs have fallen, this is the right word to be pinned on the victims of rape who are actually cornered and as if they are useless humans. The language used by the school to scrutinize the rape shows that the community still looks down on rape victims.

\section{"When did this happen? Does he use a condom?}

Has anyone seen this incident? How much have you been drinking?

Have you ever said 'no'? Are you sure you said 'no' and he heard it? Don't be too sensitive. You want it too right? "

These are excerpts from a school official when Noelle reported her case to school. As if confirming what Skye had said, that he would only become trash when he reported the rape case to school. This expression is a series of words that they use to colonize rape victims. In fact, they did not recommend a post mortem or other medical examination of victims of rape.

This language intimidates victims of rape that are not supposed to be said to a woman who becomes a victim. Even not only in language, taking pictures in this film is very demeaning to the woman who is a victim of rape. Women are likened to a slice of meat that has no taste and must accept anything when it experiences rape. Women who are victims of rape are considered weak and cheap. Even girls also hate rape victims, because they like to seduce but when invited to have sex they refuse, even though they still want it.

Other women look down on rape victims. They see rape victims as bad women. They considered women unable to do much when they were raped. They accept the patriarchal view that women are always in a guilty position. On the other hand, they think men are people who are lucky, can do whatever they like.

Women in this film are not free or not as capable as men to say what they want. In this film women are shown as the women find it difficult to express themselves even to men who are already known. Noelle failed to resist sexual violence by her college friends. In Luke's rape, Noelle is described as a woman who can only say "wait a minute" and "no, no, no". Noelle is described as a woman who does not have "power". When Noelle tried to fight with energy, Luke as a man was described as having more physical strength so Noelle was helpless. The jurisdiction used in this film also shows that good women must obey men. Like Luke's saying "be a good girl", be a good girl, okay "," be a good girl now ". The same sentence is said repeatedly so as to emphasize, that good women are women who obey what men want.

In the other sides, women are shown willingness to be raped. Many times Noelle said no. Even repeatedly asking Luke not to rape him. Noelle also tried repeatedly to escape Luke's grasp. But in the end, Luke was shown successfully raping Noelle. Noelle's failure to fight Luke was like Noelle was finally willing and willing to be raped. Women are displayed as objects, which can be treated as they please. Women do not have authority over their own bodies. In the film M.F.A., Noelle is portrayed as a woman who was enjoyed by Luke from the beginning. During the lecture, Luke was described as having enjoyed Noelle's beauty and body with his eyes. Then proceed to Luke's party invitation to Noelle who turns out to only channel sexual desire. Even after breaking his lust, Luke casually told Noelle to go home. Women in this film are described only as goods, as objects that can be enjoyed 
at any time. Women are described as having no rights to their own bodies.

Women who are rape victims are described as weak, helpless women. When Noelle tries to report the incident of raping her to the school, Skye Noelle's roommate banned her, arguing that she was worried that Noelle would be labeled a cheap and crazy woman. Because Skye had a friend who shared the same fate with Noelle when reporting it was considered a cheap woman. Skye even convinced Noelle that it was only one night's love. It is okay. If you report to the school, it will destroy Noelle's entire life. Then the best choice is to be quiet.Women who are rape victims are considered strange, and it is not natural if they are angry or demand justice after being raped. Luke just laughed out loud when Noelle demanded an apology from him. According to Luke, Noelle is too sensitive as a woman. According to Luke, what happened was not rape because he considered Noelle to also enjoy the relationship.

In front of the law, women who are raped are perceived as cheap women. As Lindsey (other rape victims) experienced even during the investigation process, the statements made led to the accusation that the rape victim had had sex before with another man. The police also consider women victims of rape to be basically seducers and teasers. As a result, the perception was that the rape carried out by men was nothing but the fault of the women as well.

The resistance of female victims of rape ultimately does not work because there is no support from the environment, even from the women themselves. Patriarchal ideologies that have taken root in society have helped perpetuate discrimination against women. When Noelle was about to report her case to the school, Skye Noelle's roommate forbade her. Lindsey, another rape victim when met by Noelle, also admitted that she regretted reporting her case to the police, because she was the one who was blamed. When Noelle tried to enter the women's community in the campus, inviting her to do a resistance movement also did not get a good response.
In the end, Noelle's struggle was stopped, and Noelle chose to fight in her own way (killing therapists).

\section{Radical Feminism Perspective}

Like what Mansour Fakih said, in this M.F.A film, there also appears to be resistance from the community such as women themselves.

Noelle's struggle to get her rights did not get a good response from her environment. He got a lot of obstacles, even from his own friends invited to be quiet and accept everything that had happened. However, Noelle continued to move and fight for her rights, women's rights to be protected from sexual predators. Noelle's efforts and efforts to get justice were not initially considered, and then drew people's attention.

When comparing women's rights groups and women's liberation groups, then connecting the first group with liberal feminism, and the second with radical feminism. But radical feminism focuses more on liberating women's rights to violence. Because Marilyn French attributed differences in men and women more to biology (nature / nature), than to socialization (nurture / nurture), I looked at French more as a radical-cultural feminist.

According to Alison Jaggar and Paula Rothenberg (Tong, 2005) claim for the interpretation of oppression against women. (1) That women have historically been the first oppressed group. (2) That oppression of women is the most widespread, and exists in almost every known society. (3) That oppression of women is the deepest which means, that this oppression is the most difficult form of oppression to be abolished, and cannot be eliminated by other social class changes, for example by the abolition of the class of society. (4) That oppression of women causes the worst suffering for victims, both quantitatively and qualitatively, even though the suffering caused arises unconsciously due to sexist prejudice, both from the oppressor and from the victim's side. (5)That oppression of women provides a conceptual understanding of other forms 
of oppression.

With the desire of men to master the combination of "women/nature" outwardly patriarchal, a hierarchical system that respects the so-called power-over. In the beginning, patriarchy was developed to ensure the survival of human communities, power-over quickly became under patriarchy, a value that grew only for the experience of being a powerful person, legal holder, boss, or number one person in the hierarchical status sequence (Tong, 2005).

French claims that feminine values must be reintegrated into male societies that have been created by patriarchal ideology. If we want to see equality, according to French, one must respect love and gentleness, as well as the willingness to share, and maintain each other equally with control and structure, sense of belonging and status.

Radical feminist perpective of sexuality has the idea that women must have control of their bodies. According to Ferguson (Tong, 2005) heterosexual relations in general are characterized by the ideology of sexual objectification (men as subjects/masters, women as objects/slaves), which supports male sexual violence against women. This is what Noelle fight for, that men are not entitled to control the female body. Sexual violence or rape experienced by Noelle is also a form of male control over women's bodies which tends to harm them. Finally men act unilaterally on female sexuality and hold control over it.

In the other argument, feminists must resist any sexual practices that support or normalize male sexual violence (Tong, 2005). Through the women's community on her collage, Noelle tried to voice women's rights and refused firmly how pressure was put on women. But the community is still silent and follows a patriarchal view that tends to harm women. Women generally do not realize that they live in a male perspective, so they justify many things to happen in their perspective.

The ideal sexual relationship is between equal partners, who both give consent, who are emotionally involved and do not take part in polarized roles (Tong, 2005). Inequality in the rape experienced by Noelle is a violation of the rights of one's body. Luke did not ask Noelle for approval of the harassment. he forced Noelle to obey his words and asked him to shut up and accept everything.

In the case experienced by Noelle, women really do not have a role and power over their sexuality. As if he did not have the power to enjoy his own body, women were considered only as objects of power over men. Even when he was raped by men, he did not have enough strength to fight. Finally, he only accepted all of the men's treatments. The female victim of rape was then pressured by patriarchal ideology that in fact she really wanted it. Not to mention the public accusations in the event of rape because women are 'cheap' or 'crazy'.

Allegations of rape victims indicate that the public sees women not as victims of rape but as a trigger for rape. When reporting on the incident, Noelle was seen as a person who was too sensitive and considered unable to enjoy the process of unwanted relations. Whereas on the contrary, he should have the right to be served in accordance with applicable legal procedures.

Because of his very clear dislike of masculine power-over values. French claims that a human who has love, must balance himself is not between pleasures with powerover, but between pleasure with the version that has been defined from the powerover that he labeled as power-to. French emphasized that it is good for humans to have power, and also enjoyment in their lives, provided that the power that emerges is not as a power-over, but rather as a desire to create power-to. Recognizing that humans may never be whole, can erase their desire to be number one, French stressed that it is possible for humans to limit their competitive impulses, and then grow the capacity for collaboration between them.

\section{Women's Solidarity and Sisterhood}

Interesting thing in the film M.F.A. is how Noelle finished off the perpetrators of 
rape. The man who raped himself, the rapists Lindsey, and the person who raped and made Skye depressed. The way Noelle killed was very tragic like a psychopath, he did not know forgiveness. All he did was a sense of disappointment towards the community that did not provide a defense for the rape that had befallen him and his friends. People blame and judge rape victims.

In the concept of sisterhood, when humans face each other, one can change that relationship. Sisterhood was born because of the concept of motherhood. Apart from being a union of mothers, women build brotherhood, women's unity dedicated to women. This sisterhood sometimes involves mutual nurturing and mutual teaching for mothers. Sometimes brotherhood makes a sister (not biological), stand by someone to comfort her or help her do what must be done. Sometimes brotherhood means being a good friend, a place to hear or lean your shoulders. Sometimes brotherhood invites you to have fun together, work on tasks to raise children and have fun and friendly households. Sometimes brotherhood means rolling up your sleeves and diving into unpleasant things, whether it is cleaning up basement floods or exhausting marriages that are done together (Solomon, 2007). Sisterhood means binding, defending, helping, and helping (female) brothers who are in need. Live a day with a variety of jobs ranging from the fun to the annoying things together.

Sometimes a woman stands alone, is not recognized in her vision, and only brotherhood will support her in developing her talents and talents and fulfilling her goals (Solomon, 2007). When depressed thinking about what happened that night, Noelle told Skye everything, because she was sure that she could not bear the burden alone. As a friend or sibling (not biological), Skye keeps trying to strengthen Noelle. Their relationship is very close, because they spend a lot of time together and share anything, either fun or unpleasant things.

One of the beautiful things about brotherhood is that a person does not need to be anything that cannot be fulfilled for what is needed in a relationship. In fact, a woman's weakness creates the need for other people's strengths, and vice versa (Solomon, 2007). A woman has had a hard time with her family. Her husband was fired, his son died, even his parents divorced, women's brotherhood could fulfill their needs and provide comfort. They could live with relatives, but it didn't feel as comfortable as being together in a brotherhood of women. Troubled women can just walk aimlessly for a few moments, but they will find a place to go home to their relatives.

Sisterhood telling each other when needed, regardless of age or social strata. A group of women of various ages and incomes can embrace young pregnant women. They provide voluntary assistance, giving space for girls to talk about their fears, hopes, and dreams without judging them. Every older woman chooses a young woman to be a mentor, promises their commitment over the long term and they are serious (Solomon, 2007).

\section{CONCLUSION}

Semiotic analysis on the text of blaming the victim film M.F.A shows that female rape victims must suffer the consequences themselves. The impact that was received by the victim was the assumption from the community that the victim was a seductress, seducer, and therefore worthy of being raped (Blaming the Victim). Rape victims were also labeled as cheap women. If the victim reports the incident of rape that happened to him, then he will be labeled as a "crazy" woman. Women who are victims of rape are also considered to enjoy the rape committed by men (Blaming the Victim). This assumption was accepted by the community because the victim was considered not to refuse, did not fight when raped. In the realm of law, only women victims are tried, while male rapists are free to walk without guilt, and are free to continue to live without any burden. This is the current media image. The researcher's task is to show the public. And filmmakers should be more gender perspective. That men and women are equal. Their position before the law is also the same. So when 
making films, the films produced are films with a gender perspective, not films that are gender biased.

\section{References}

Adipoetra, F. G. (2016). Representasi patriarki dalam film Batas. E Komunikasi, 4(1), 1-11.

Barthes, R. (1974). S/Z. New York: Hill \& Wang.

Byerly, C. M. and K. R. (2006). Women and media, a critical introduction. Australia: Blackwell Publishing.

Chandler, D. (2007). Semiotics the basics (Second). USA and Canada: Routledge.

Fakih, M. (2008). Analisis gender dan transformasi sosial. Yogyakarta: Pustaka Pelajar.

Jaya, A. S. (2014). Representasi seksualitas perempuan dalam film Suster Keramas. Jurnal The Messenger, 6(2), 1-7. http:// dx.doi.org/10.26623/themessenger. v6i2.188

Komisi Nasional Perempuan. (2019). Catatan tahunan kekerasan terhadap perempuan 2019.

Laoera, B. D. (2016). Membaca konstruksi seksualitas: Sebuah kajian resepsi mahasiswi santri terhadap film perempuan punya cerita. Prosiding Konferensi Internasional Feminisme: Persilangan Identitas, Agensi Dan Politik (2o Tahun Jurnal Perempuan), 52-92.

Lestari, A. P. (2017). Penonton anak dan remaja terkait program acara Indonesian Idol Junior 2016: Studi resepsi pada kontestan anak yang menyanyikan lagu-lagu orang dewasa. Jurnal The Messenger, 9(1), 55-64. http://dx.doi.org/10.26623/ themessenger.v9i1.427
Lestari, A. P. (2018). Blaming the victim: Kekerasan simbolik berupa alienasi gender korban pemerkosaan pada berita asusila di Suara Merdeka.Com. Diponegoro University.

Morissan. (2013). Teori komunikasi: Individu hingga massa. Jakarta: Prenadamedia Group.

Putri, D. M. A. (2012). Blaming the victim: Representasi perempuan korban pemerkosaan di media massa (Analisis semiotika dalam pemberitaan di koran Suara Merdeka Desember 2011 - Februari 2012). 1(1), 1-15.

Setiawan, Y. B. (2011). Analisis wacana kritis pemberitaan kekerasan berbasis gender di surat kabar harian Suara Merdeka. Komunikasi Makna, 2, 1-20.

Solomon, D. A. (2007). The sisterhood: Inside the lives of mormon women. New York: Palgrave MacMillan.

Susanty, D.I. \& Julqurniati. N. (2019). Kekerasan terhadap perempuan dalam rumah tangga di Flores Timur. Sosio Konsepsia, 8(2), 139-156.

Tanjung, S., \& Ramanda, I. (2019). Semiotics of border (analysis of Batas, a film of Rudi Soedjarwo). Informasi, 49(1), 3749. https://doi.org/10.21831/informasi. v49i1.25396.

Tong, R. P. (2005). Feminist thouhgt: Pengantar paling komprehensif kepada arus utama pemikiran feminis. Yogyakarta: Jalasutra.

Webb, J. (2009). Understanding representation. London: Sage Publications ltd. 